\title{
Taxonomical Investigation, Chemical Composition, Traditional Use in Medicine, and Pharmacological Activities of Boswellia sacra Flueck
}

\author{
Mansour Miran (D), ${ }^{1}$ Keyvan Amirshahrokhi, ${ }^{2}$ Yousef Ajanii, ${ }^{3}$ Reza Zadali, \\ Maxwell W. Rutter, ${ }^{5}$ Ayesheh Enayati, ${ }^{6}$ and Farahnaz Movahedzadeh ${ }^{7,8}$ \\ ${ }^{1}$ Department of Pharmacognosy, School of Pharmacy, Ardabil University of Medical Sciences, Ardabil, Iran \\ ${ }^{2}$ Department of Pharmacology, School of Pharmacy, Ardabil University of Medical Science, Ardabil, Iran \\ ${ }^{3}$ Botany Division, Research Institute of Forests and Rangelands, \\ Agricultural Research Education and Extension Organization (AREEO), Tehran, Iran \\ ${ }^{4}$ Department of Pharmacognosy, Faculty of Pharmacy, Islamic Azad University-Damghan Branch, Iran \\ ${ }^{5}$ Hollingbery \& Son, Inc, Yakima, WA 98902, USA \\ ${ }^{6}$ Ischemic Disorders Research Center, Golestan University of Medical Sciences, Gorgan, Iran \\ ${ }^{7}$ Institute for Tuberculosis Research, University of Illinois at Chicago, Chicago, IL, USA \\ ${ }^{8}$ Department of Pharmaceutical Sciences, University of Illinois at Chicago, Chicago, IL, USA
}

Correspondence should be addressed to Mansour Miran; mansour.miran@gmail.com

Received 29 October 2021; Revised 8 January 2022; Accepted 11 January 2022; Published 18 February 2022

Academic Editor: Mohammed Bourhia

Copyright $\odot 2022$ Mansour Miran et al. This is an open access article distributed under the Creative Commons Attribution License, which permits unrestricted use, distribution, and reproduction in any medium, provided the original work is properly cited.

\begin{abstract}
Aromatic oleo-gum-resin secreted from B. sacra, reputed as frankincense, is widely used in traditional medicine to treat Alzheimer's disease, gastric disorders, hepatic disorders, etc. Frankincense is also used in the cosmetic, perfume, and beverage and food industries. Frankincense is a rich resource for bioactive compounds, especially boswellic acids and derivatives. Although several reports have described frankincense's constituents and pharmacological activities, there is no comprehensive study that covers the valuable information on this species. Therefore, the current review will focus on the phytochemistry, traditional uses, and pharmacological activities of B. sacra.
\end{abstract}

\section{Introduction}

Boswellia sacra Flueck is a perennial plant belonging to the family Burseraceae. Aromatic oleo-gum-resin extracted from B. sacra, known as frankincense or olibanum (Figure 1), is used as a home remedy, especially in Middle East countries [1]. Frankincense is harvested by making shallow incisions into the tree trunk [2]. Frankincense is used in many industries such as cosmetic, pharmaceutical, beverage, food, detergents, and perfume industries [3,4]. The oleo-gum resin of B. sacra has many uses for the human body, including analgesic, hepatoprotective, anticoagulant, antioxidant, tumor-suppressive, anti-inflammatory, cardioprotective, Alzheimer's disease, gastric, hepatic, and skin disorders $[5,6]$. B. sacra is an important source of bioactive compounds, including terpenoids which have a wide range of biological activities [6]. The most important compounds found in resin from Boswellia sacra are boswellic acids and their derivatives, which are responsible for a number of medicinal properties belonging to the plant.

Accordingly, this review introduces $B$. sacra as a valuable herbal source in different industries such as pharmacy and food.

\section{Genus Boswellia Roxb. Ex. Colebr}

The genus Boswellia belongs to the family Burseraceae. It comprises 20-25 species of trees and shrubs widely distributed in dry areas of northeast Africa, Arabia, and India 


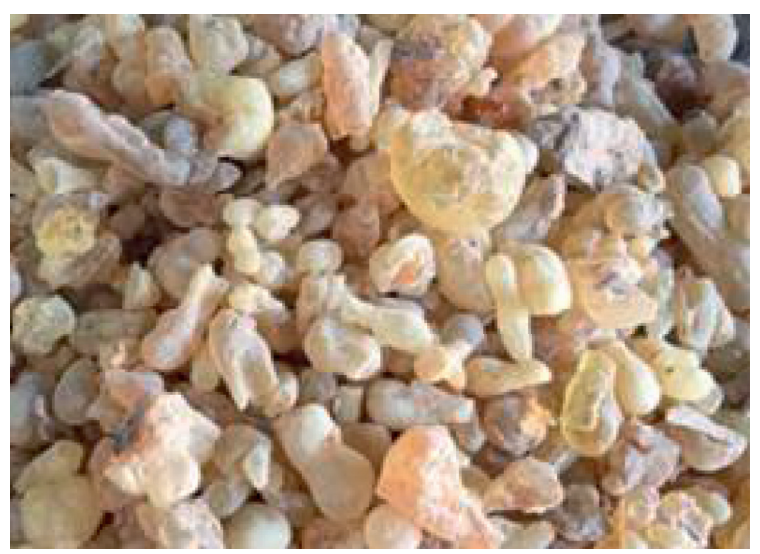

Figure 1: A photograph of frankincense gum resin taken from https://nagaadgums.com.

$[7,8]$. Species of the genus, known as frankincense trees (olibanum), produce a resin gum traditionally harvested by making incisions on the trunks of the trees; as the resin is exposed, it darkens and hardens before being removed from the incision [9]. Among the species of the genus, only $B$. serrata Roxb. and $B$. sacra Flueck have economic importance.

The taxonomy of Boswellia (five species) except B. papyrifera (Del.) Hochst. in northern Somalia and southern Arabia has been revised. Therefore, the two extreme populations of Boswellia spp. vary in habitat, indumentum and shape of leaflets, number of inflorescence branches, and shape of fruits. There are also populations showing the intermediate characteristics of the extremes in Somalia and the Arabian Peninsula. Based on flower and fruit features, $B$. sacra is closely related to $B$. papyrifera. The genus has been reduced to two species, including $B$. sacra Flueck and B. frereana Birdwood. Based on morphological data, B. carterii Birdwood has been synonymized with $B$. sacra [10]. However, recent chemical analysis has shown that these are distinct species [11]. To confirm this data, further taxonomical research is required. B. sacra is typified as follows:

Boswellia sacra Flueckiger, Lehrbuch der Pharmakognosie des Pflanzenreiches [12].

Syn.: B. carteri Birdwood var. subintegra Engel., B. bhaudajiana Birdwood var. serrulata, B. carteri Birdwood var. undulate-crenata Engel. B. undulato-crenata (Engl.) Engel. [10].

2.1. Botanical Description, Habitat, and Distribution. B. sacra is a tree with a distinct trunk that grows to a height of $1.5-8 \mathrm{~m}$. The stems branch from the base, having pale yellowish-brown bark. The young stems can be either hairy or smooth. Resin is copious on the bark. It is milky when first exposed, then pale yellowish when dried. Leaves are densely crowded, arranged as alternates and imparipinnate with 13-19 leaflets. The inflorescence is either raceme or panicle. The flowers emerge synchronously with leaves. Pedicel length is $2-8 \mathrm{~mm}$, covered with sparse hairs or smooth. Calyx is cup-shaped; the color is reddish-brown and reaches between 2 and $2.5 \mathrm{~mm}$ in length. Petals are white and elliptic, and the dimension is $4-5 \times 2-2.5 \mathrm{~mm}$. Stamens are numerous, approximately 10 . The filament texture is smooth; the length is $2.5-3 \mathrm{~mm}$. The anthers are oblong and white. The texture can be hairy or smooth. The length is $0.8-1.4 \mathrm{~mm}$. The flowers are yellowish to orange. The pistil is furrowed, smooth, and $2.5-3 \mathrm{~mm}$ in length. The fruit is pyriform, reddish-brown, and has 3-4 locules. The dimension is $8-12 \times 3.5-9 \mathrm{~mm}$. Pyrenes are trigonous and often surrounded by a persistent wing. The dimension is $3.5-5.5 \times 2-4.5 \mathrm{~mm}$.

Carter first collected this species from Arabia [13]. He incorrectly named the species as B. thulifera and B. serrate. Flueckiger [14] identified it as B. papyrifera and later correctly identified it as a new species "B. sacra" in 1867 [10].

$B$. sacra is mainly a saxicolous species. The cushion or disklike swelling base of the trunk adheres the plant to the rock faces. This plays an important role in stabilizing the plant, especially in very steep terrain. This species is distributed in Somalia, most parts of the Horn of Africa, and up to the Arabian Peninsula [15]. The plant growing in control and wild habitats is shown in Figure 2.

\section{Traditional Medicine}

The resin of frankincense is commonly used to treat bronchial and urinary infections. It is used as a rejuvenating medicine and treats menstrual pain, mouth problems, wounds, sores, ulcers, carbuncles, hemorrhoids, inflammation, and throat problems in some Asian countries. It is also known that frankincense oil has carminative, digestive, and diuretic properties. This gum resin's water extract, known as "Moh-Lubban," is traditionally used to treat coughs and stomach problems [1].

In Oman, B. sacra gum extracts have long been used in various folk medicines for strengthening and stimulating the digestion process, dental infections, and for the treatment of colds, cough, muscle pain, fever, and asthma, as well as different types of cancer [16, 17]. In Arabian folk medicine, the gum resin is reputed to improve memory [18].

\section{Chemical Composition}

Frankincense gum resin contains $5-9 \%$ oil, a $60-70 \%$ alcohol-soluble fraction, and a $25-30 \%$ water fraction. The lipophilic part is a rich source of terpenoids, especially the medicinally important group of boswellic acids (BAs) $[6,19]$. Plant resins are lipid-soluble mixtures of volatile and nonvolatile terpenoids [5].

4.1. Volatile Terpenoids. The chemical composition of the volatile oil of $B$. sacra resin has been investigated by GC-FID, GC/MS, and headspace SPME methods that revealed $\alpha$-pinene (38\%) (1), $\beta$-ocimene $(32.3 \% ; 2)$, camphene $(29.4 \% ; 3)$, 1-propanol, 2-(2-hydroxypropoxy) (14.4\%; 4), limonene $\left(13.36 \%\right.$; 5), and 2- propanol, $1,1^{\prime}$-oxybis $(11.2 \% ; 6)$ as the main compounds. Also, other compounds such as trans-pinocarveol (3.98\%) (7), caryophyllene (3.03\%; 8), cis-piperitol (2.53\%; 9), $\beta$-selinene (2.49\%; 10), myrcene (2.38\%; 11), $\alpha$-phellandren-8-ol 


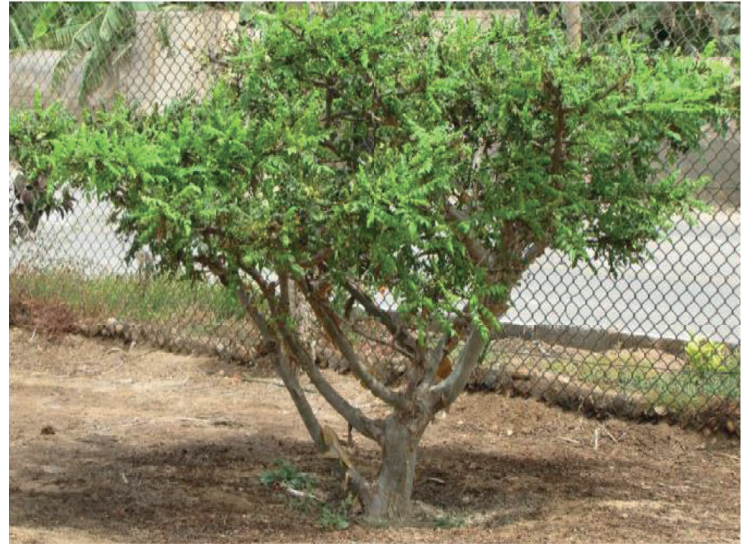

(a)

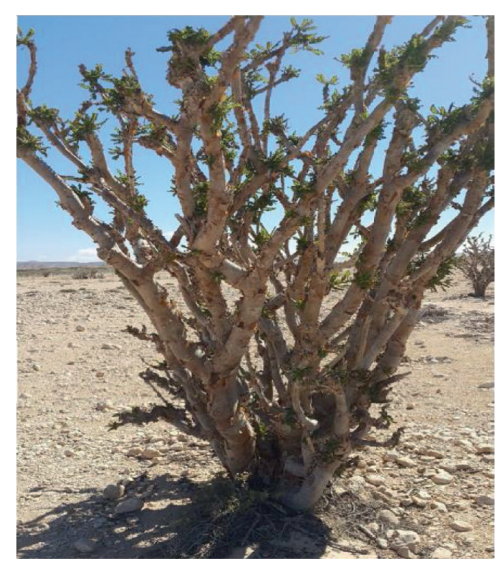

(b)

FIgURE 2: Photographs of (a) tree growing in control habitat; (b) tree growing in wild habitats given by Khan et al. [5].

$(2.37 \% ; 12)$, and delta-cadinene $(2.21 \% ; 13)$ have been reported in significant amounts in the essential oil from B. sacra (21-23) (Figure 3).

4.2. Sesquiterpenoids. Investigation of $B$. sacra led to the isolation and identification of two oxygenated sesquiterpenes, namely, rotundone (14) and mustakone (15) [24] (Figure 4). These compounds were isolated from the volatile oil of gum resin by sensory-guided fractionation [24].

4.3. Diterpenoids. Four new cembrane-type diterpenoids, including boscartins (16-19), together with five known compounds (1S, $3 \mathrm{R}, 11 \mathrm{~S}, 12 \mathrm{R}, 7 \mathrm{E})$-1,12-epoxy-4-methylenecembr-7-ene-3,11-diol (20), isoincensole oxide (21), incensole oxide (22), incensole acetate (23), and incensole oxide acetate (24) were isolated from $B$. sacra gum resin by Wang et al. In addition, hepatoprotective properties of isolated compounds were studied against HepG2 cells that had been damaged by paracetamol compared to bicyclol (as a positive control). Incensole acetate had a potent hepatoprotective effect at $10 \mu \mathrm{M}$. In contrast, boscartin $\mathrm{M}$, isoincensole oxide, incensole oxide, and incensole oxide acetate had a mild hepatoprotective effect at $10 \mu \mathrm{M}$ [25]. In the other report by Wang et al., the investigation of $B$. sacra led to the isolation of ten new cembrane-type diterpenes, including boscartins AL-AU (25-34) and five known analogs (35-39). Moreover, biological evaluations revealed that compounds 27, 29, 36, and 37 displayed hepatoprotective activities against paracetamol-induced HepG2 cell damage at $10 \mu \mathrm{M}$. Some compounds exhibited moderate neuroprotective activities in two different models [26]. Zhang et al. isolated eight diterpenoids (40-48), namely, sacraoxides A-G from the gum resin of $B$. sacra and found that sacraoxides $\mathrm{E}$ and $\mathrm{F}$ had inhibitory activities on nitric oxide (NO) production induced by lipopolysaccharide in RAW264.7 cells with $\mathrm{IC}_{50}$ values of $24.9 \pm 1.7$ and $36.4 \pm 2.9 \mu \mathrm{M}$ [27]. In another study, five diterpenoids (49-53) including two new prenylaromadendrane-type diterpenoids, and three known analogues, were isolated from the ethanol extract of the gum resin of B. sacra Flueck by Wang et al.. All compounds exhibited notable cytotoxicity against human malignant glioma (U87-MG) cell line against 5-fluorouracil as a positive control [28]. Figure 5 shows the structures of isolated diterpenoids from B. sacra.

4.4. Triterpenoids. B. sacra could be chemically characterized by the occurrence of triterpenoid compounds such as lupeolic acid, $\alpha$ - and $\beta$-boswellic acids (54, 55, and 56), and their respective $\mathrm{O}$-acetyl derivatives $(57,58$, and 59) [28]. Ali et al. isolated two new $\mathrm{O}$-acetyl derivatives of pentacyclic triterpenic acids, $3 \alpha$-acetoxyurs-5:12-dien-24-oic acid (60) and 3-acetoxylup-12:20-dien-24-oic acid (61) [29] from Omani frankincense of $B$. sacra along with four known compounds: commic acid-D (62), 9,11-dehydro-boswellic acid (63), 3- hydroxy-11-oxours-12-ene (64), and 11-hydroxy-3-oxours-12-ene (65) [30]. One ursane-type (66), one oleanane-type (67), namely, olean-11,13(18)-dien-3 $\beta, 24$-diol and 3-oxo-11a-hydroxy-urs-12-ene, respectively, as well as two lupane-type triterpenoids, lupeolic acid (68) and lupeol (69), have been reported by Al-Harrasi et al. from the resin of $B$. sacra [17]. The frankincense resin of $B$. sacra was pyrolyzed, and the smoke was trapped into water using a self-developed assembly. Two compounds, namely, 1,2,4a,9tetramethyl-1,2,3,4,4a,5,6,14b-octahydropicene (70) and 2,9-dimethylpicene (71) were isolated from an n-hexane extract of the smoke-saturated water. Compounds 70 and 71 were evaluated for their antiproliferative activity against MDA-MB-231 breast cancer cells, and it was observed that these pyrolysate products were able to inhibit cancer cell growth [31]. A new ursane-type triterpene, namely, nizwanone (72) was reported from Omani frankincense B. sacra Flueck along with two known compounds papyriogenin B (73) and rigidenol (74) by Al-Harrasi et al. [32]. 11-ketoursolic acid (75), 3 $\alpha$-hydroxy-8, 24-dien-tirucallic acid (76), 3-O-acetyl-oleanolic acid (77), and 3-O-acetyl-ursulic acid (78) were reported as triterpenoid compounds from a methanolic extract [33]. Similarly, ten more known compounds were isolated from the resin of $B$. sacra including one 


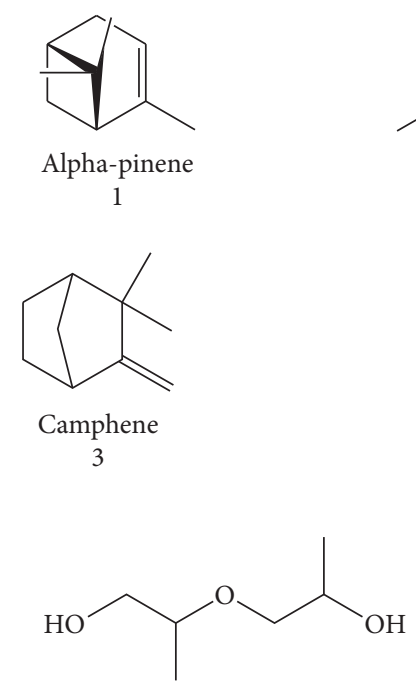

1-propanol, 2-(2-hydroxypropoxy)

4<smiles>CC(O)COCC(C)O</smiles>

2-propanol, 1, 1'-oxybis 6

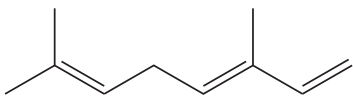

Beta-ocimene

2

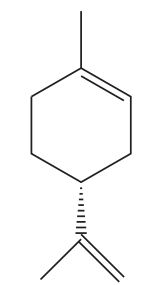

Limonene

5

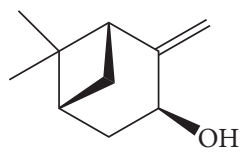

Trans-pinocarveol

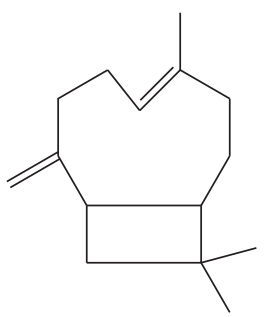

Caryophyllene

8<smiles>CC1=C[C@H](O)[C@H](C(C)C)CC1</smiles>

Cis-piperitol 9<smiles>C=CC(=C)CC/C=C/C</smiles>

Beta-selinene

10

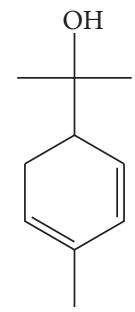

Alpha-phellandren-8-ol

12
Myrcene

11<smiles>CC1=C[C@]2(C)C(=C(C)CC[C@@H]2C(C)C)CC1</smiles>

Delta-cadinene 13

(a)

(b)

FIgURE 3: The chemical composition of the volatile oil of B. sacra resin.

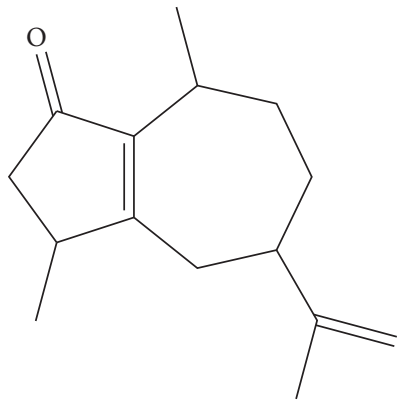

14

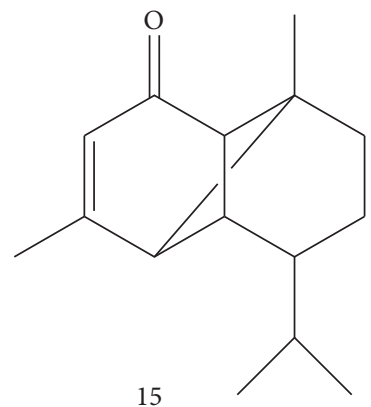

15
FIgURE 4: Sesquiterpenoids isolated from B. sacra.

triterpene (79) [34]. Structures of isolated triterpenoids from B. sacra are shown in Figure 6.

4.5. Boswellic Acids and Derivatives. The primary active components from the extract of $B$. sacra are boswellic acids (BAs). As shown in Figure 7, BAs are a group of oleanane or ursane pentacyclic triterpenoids with carboxylic acid at C- 4 and are divided into two groups, $\beta$-BAs (ursane-type) and $\alpha$-BAs (oleanane-type). Their potency against inflammation, arthritis, ulcerative colitis, chronic colitis, asthma, and hepatitis is well documented. They also have exhibited antimicrobial, antidiabetic, antiviral, and antipruritic activity. One of the important uses of BAs in medicine is as an anti-inflammatory. Boswellic acids suppress leukotriene biosynthesis in neutrophilic granulocytes by nonredox, noncompetitive inhibition of 5-lipoxygenase [32, 35-37]. The pharmacological effects of $B$. sacra extract are commonly explained by the presence of boswellic acids [36]. Also, the anticancer activity of BAs is remarkable. In this regard, they have activity against cancers including bladder, brain, cervical, colon, colorectal, liver, leukemia, lung, melanoma, meningioma, multiple myeloma, neuroblastoma, ovarian, pancreatic, and prostate [38].

A new boswellic acid derivative, $11 \alpha$-ethoxy- $\beta$-boswellic acid (EBA; 80), was isolated from Omani frankincense B. sacra Flueck by Al-Harrasi et al. [32]. They also reported the isolation of five boswellic acid derivatives (81-85) from the resin of $B$. sacra [17]. Similarly, ten more known compounds were isolated from the resin of $B$. sacra such as nine boswellic acids (86-91 and 92-94). Compounds 87 and 89-91 were found to be significantly active against $\alpha$-glucosidase with an $\mathrm{IC}_{50}$ value ranging from $15.0 \pm 0.84$ to $80.3 \pm 2.33 \mu \mathrm{M}$, while 92 exhibited moderate activity with an $\mathrm{IC}_{50}$ of $799.9 \pm 4.98 \mu \mathrm{M}$ [34]. 11-keto- $\beta$-boswellic acid (95), 3-O-acetyl-11-keto- $\beta$-boswellic acid (96), $\alpha$-boswellic acid (97), $\beta$-boswellic acid (98), 3-O-acetyl- $\alpha$-boswellic acid (99), and 3-O-acetyl- $\beta$-boswellic acid (100) were isolated as 


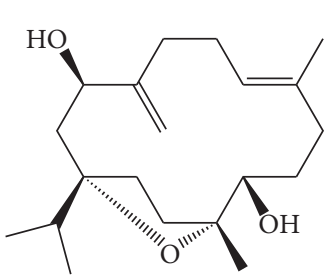

16

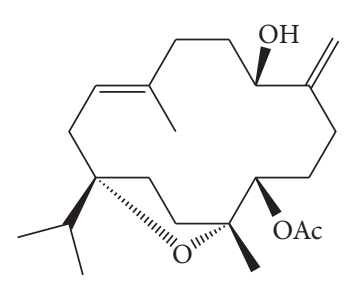

18

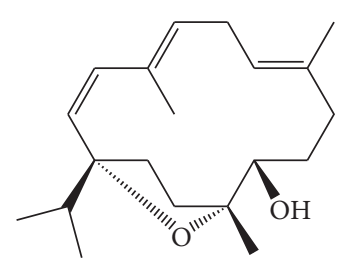

20

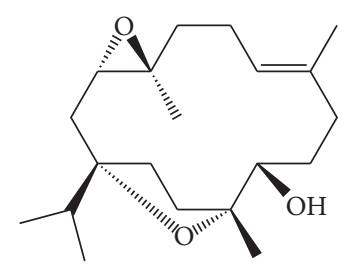

22

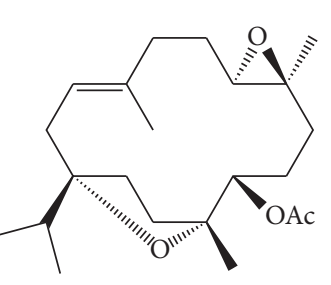

24

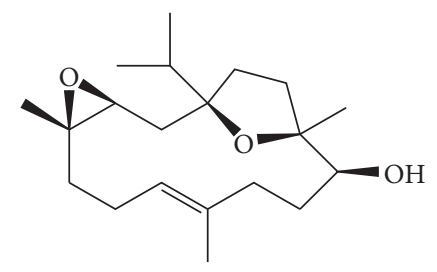

25

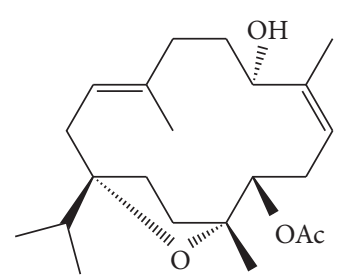

17

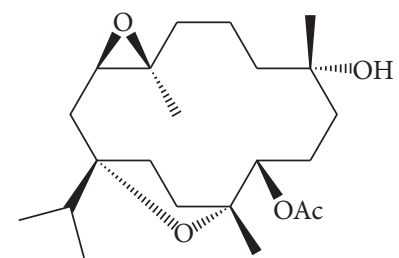

19

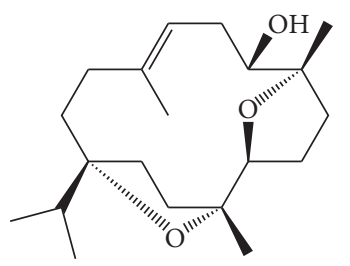

21

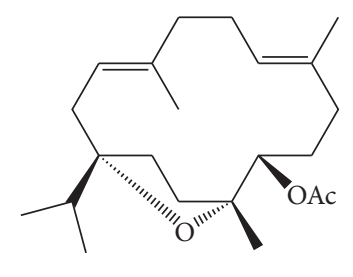

23

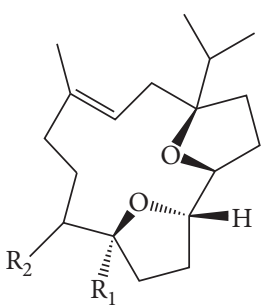

$26 \mathrm{R}_{1}$ Alpha, CH3, $\mathrm{R}_{2}$ Alpha OH 28

$39 \mathrm{R}_{1}$ Beta, CH3, $\mathrm{R}_{2}$ Beta OH 37

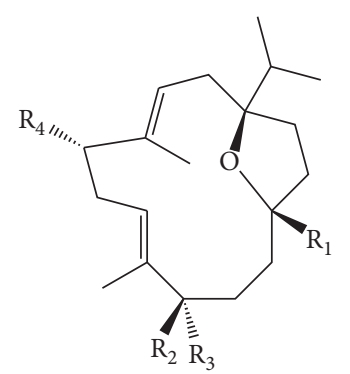

$29 \mathrm{R}_{1} \mathrm{OAc}, \mathrm{R}_{2} \mathrm{H}, \mathrm{R}_{3} \mathrm{OH}, \mathrm{R}_{4} \mathrm{H}$

$32 \mathrm{R}_{1} \mathrm{OH}, \mathrm{R}_{2}=\mathrm{R}_{3}=\mathrm{H}, \mathrm{R}_{4} \mathrm{H}$

$36 \mathrm{R}_{1} \mathrm{OH}, \mathrm{R}_{2}=\mathrm{R}_{3}=\mathrm{O}, \mathrm{R}_{4} \mathrm{H}$

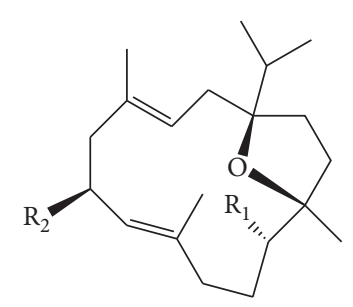

$31 \mathrm{R}_{1} \mathrm{OH}, \mathrm{R}_{2} \mathrm{OAc}$

$35 \mathrm{R}_{1} \mathrm{OAc}, \mathrm{R}_{2} \mathrm{OH}$

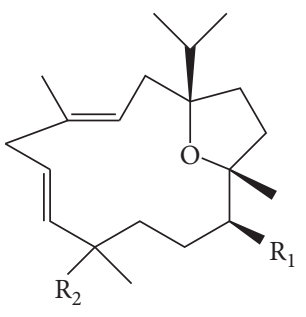

$27 \mathrm{R}_{1} \mathrm{OH}, \mathrm{R}_{2}$ Alpha $\mathrm{OH}$

$\mathrm{R}_{1} \mathrm{OAc}, \mathrm{R}_{2}$ Alpha $\mathrm{OH}$

$7 \mathrm{R}_{1} \mathrm{OAc}, \mathrm{R}_{2}$ Beta $\mathrm{OH}$

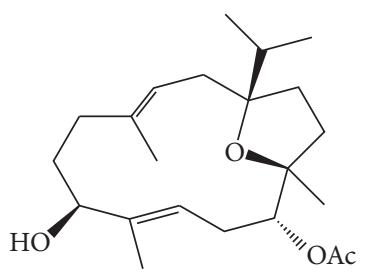

30

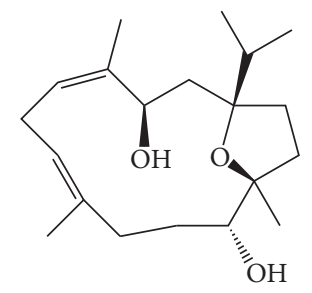

33

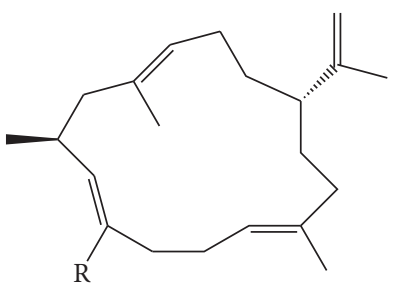

$34 \mathrm{R} \mathrm{CH} 2 \mathrm{OH}$

38 R $\quad$ CH3

(b)

Figure 5: Continued. 


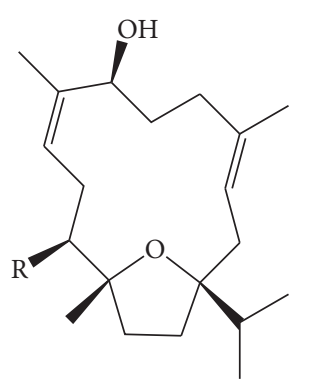

$40 \mathrm{R} \mathrm{OH}$

41 R OAc<smiles>[R]C1C/C=C(/C)[C@@H](O)CC/C(C)=C/C[C@]1(CC[C@]1(C)C[C@H](C)O1)C(C)C</smiles><smiles>B</smiles>

$42 \mathrm{R} \mathrm{OH}$

43 R OAc

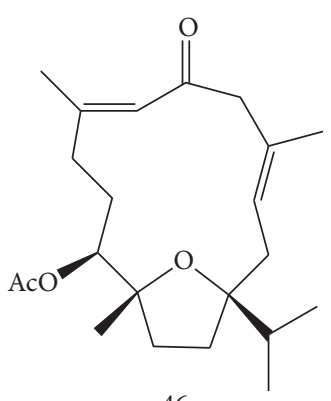

46

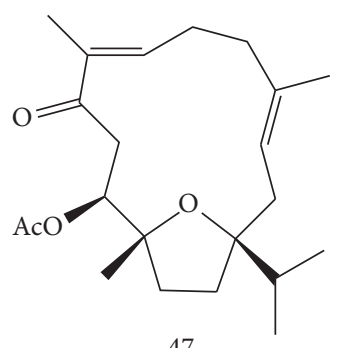

47

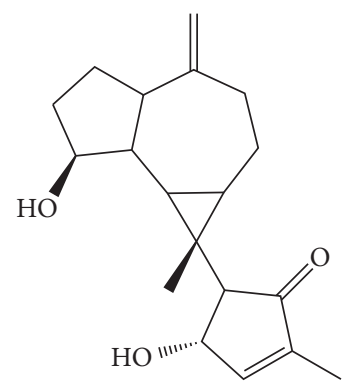

49

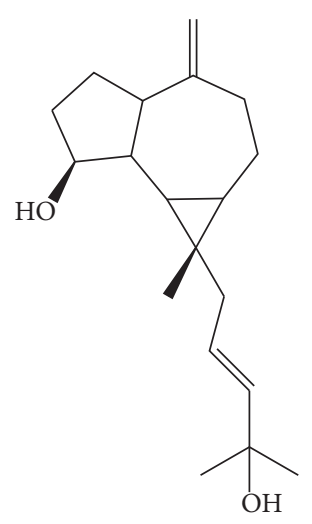

52

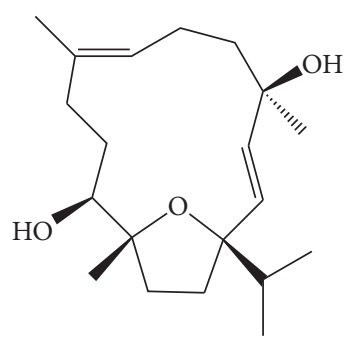

48

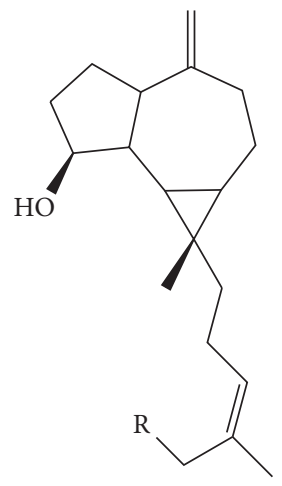

50 R OAc

$51 \mathrm{R} \mathrm{OH}$

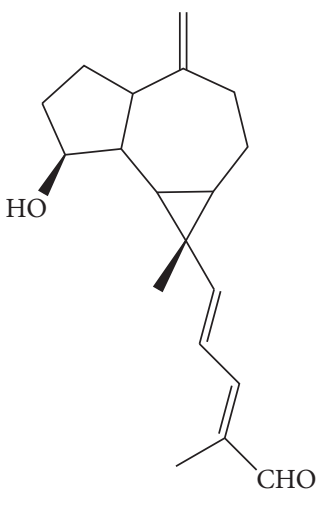

53

(c)

(d)

FiguRE 5: Structure of isolated diterpenoids from B. sacra.

boswellic acid derivatives from a methanolic extract [33]. Structures of the isolated boswellic acids and their derivatives from B. sacra are shown in Figure 8.

\section{Standardization}

The used part of the plant is an oleo gum resin that is easily found in herbal stores. For standardization of the oleo gum resin, boswellic acids and their derivatives have been accounted as standard markers [1].

\section{B. sacra Products}

There are B. sacra essential oils as liquid form, for example in $10 \mathrm{ml}$ bottles (Figure 9).

\section{Bioactivities and Professional Pharmaceutical Applications}

7.1. Anticancer Activity. The essential oil of B. sacra has been found to induce breast cancer cell-specific cytotoxicity. B. sacra essential oil can suppress tumor aggressiveness in drug-resistant and cultured metastasized human breast cancer cells. B. sacra showed proapoptotic, antiproliferative, and anti-invasive properties in human breast cancer cell lines [39]. Essential oil from B. sacra suppresses viability and induces apoptosis in human pancreatic cancer cell lines. Frankincense essential oil activates the caspase-dependent apoptotic pathway, Akt and Erk1/2 signaling molecules and suppresses the levels of cyclin D1 (an important cell cycle regulator) expression in human pancreatic cancer cells. 


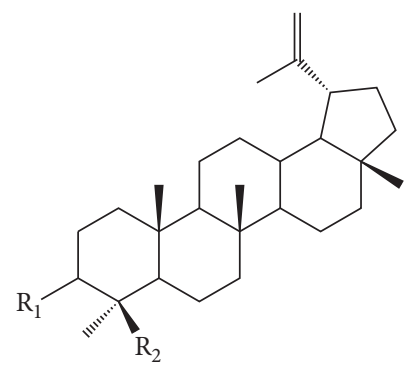

$54 \mathrm{R}_{1}$ Alpha- $\mathrm{OH}, \mathrm{R}_{2} \mathrm{CO} 2 \mathrm{OH}$

$57 \mathrm{R}_{1}$ Alpha-OAc, $\mathrm{R}_{2} \mathrm{CO} 2 \mathrm{OH}$

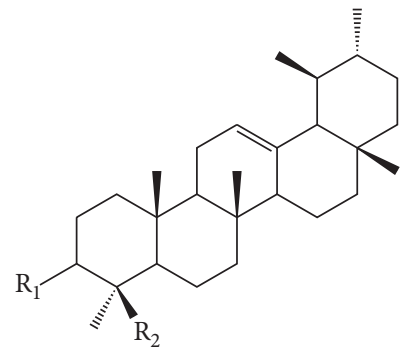

$56 \mathrm{R}_{1}$ Alpha-OH, $\mathrm{R}_{2} \mathrm{CO} 2 \mathrm{OH}$

$59 \mathrm{R}_{1}$ Alpha-OAc, $\mathrm{R}_{2} \mathrm{CO} 2 \mathrm{OH}$

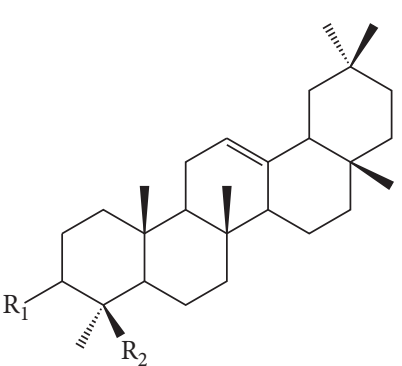

$55 \mathrm{R}_{1}$ Alpha-OH, $\mathrm{R}_{2} \mathrm{CO} 2 \mathrm{OH}$

$58 \mathrm{R}_{1}$ Alpha-OAc, $\mathrm{R}_{2} \mathrm{CO} 2 \mathrm{OH}$<smiles></smiles>

(a)<smiles></smiles>

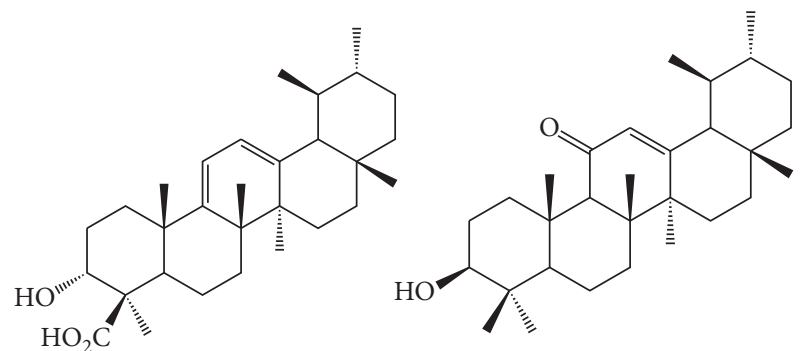

63

64<smiles>C[C@H]1CC[C@]2(C)CC[C@]3(C)C(=C[C@H](O)C4[C@@]5(C)CCC(=O)C(C)(C)C5CC[C@]43C)[C@@]2(C)CC[C@H](O)[C@@]1(C)CO</smiles>

(b)

FIgURE 6: Continued. 


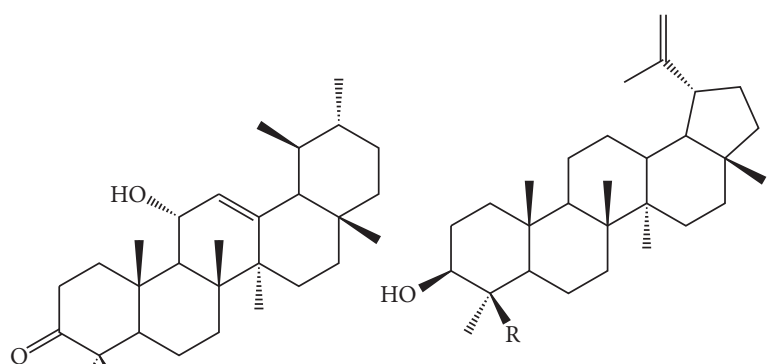

$68 \mathrm{R} \mathrm{CO} 2 \mathrm{H}$

67<smiles>Cc1ccc2ccc3c(ccc4c5cccc(C)c5ccc43)c2c1</smiles>

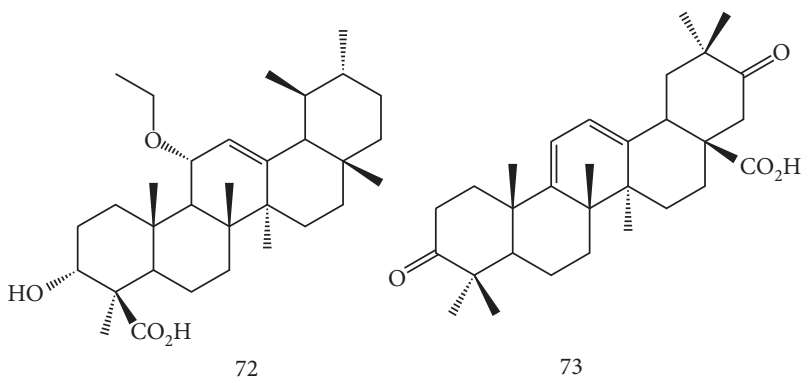

(c)

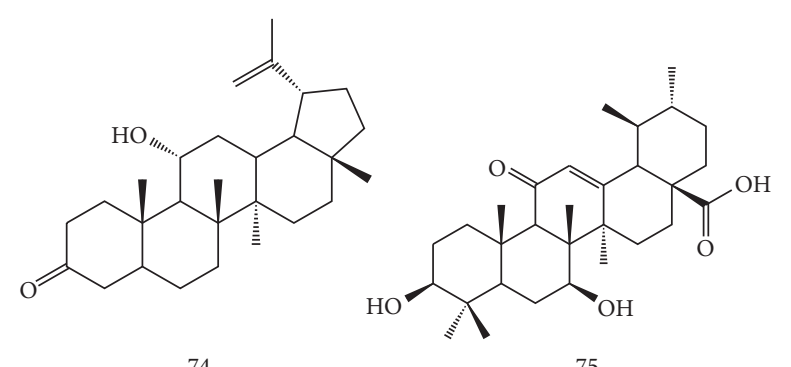<smiles>CC(C)=CCCC1C2=C(CCC1C(=O)O)C1(C)CCC3C(C)(C)C(O)CCC3(C)C1CC2</smiles><smiles>CC(=O)OC1CCC2(C)C3CCC4C5CC(C)(C)CCC5(C(=O)O)CC[C@]4(C)C3CCC2C1(C)C</smiles>

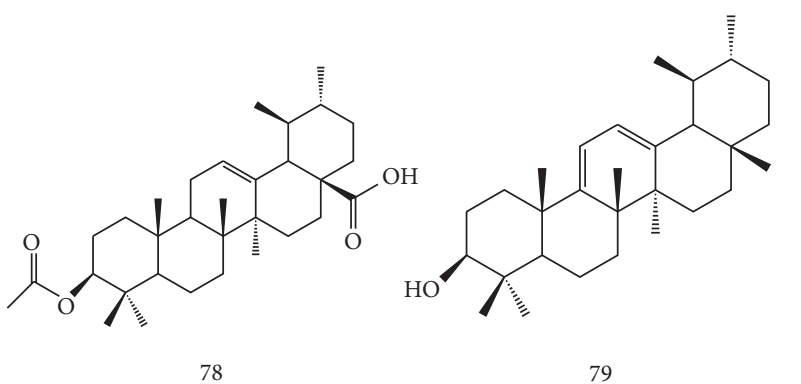
79

(d)

Figure 6: Structure of isolated triterpenoids from B. sacra.

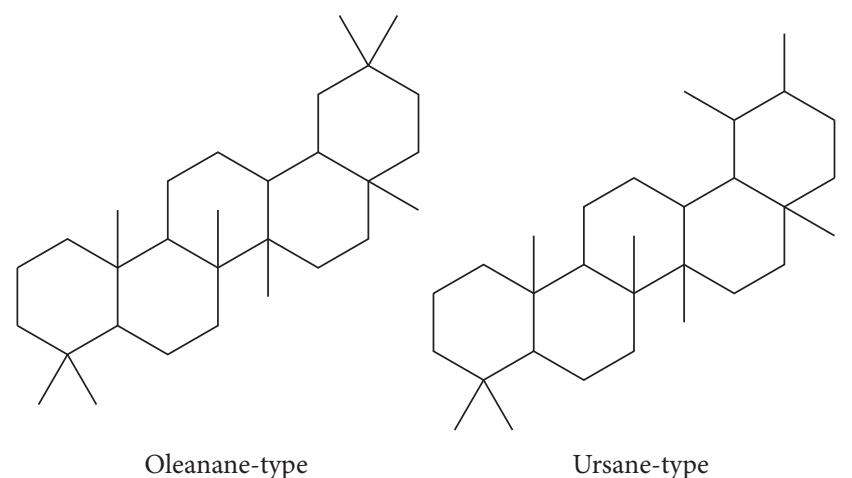

Figure 7: Basic structure of triterpenoids in BAs.

Essential oil of B. sacra gum resin has been suggested as a useful alternative therapeutic agent for patients with pancreatic adenocarcinoma, the major type of aggressive pancreatic cancer [40]. Besides, another study proposed that the essential oil was potent against colon cancer cells such as CD133+ and CD133-Colo-320 cells, and it was also considered that essential oil obtained from B. sacra led to a reduction of $\beta$-catenin signaling molecules which have a vital role in cancer cell proliferation [41]. In a case report study, oral administration of $B$. sacra gum resin was reported to be effective in urothelial cell carcinoma [42].

7.2. Analgesic Effects. The analgesic effects of crude extracts and fractions of Omani frankincense obtained from B. sacra were studied in two mouse models of pain. Administration of the extract, essential oils, and subfractions from the resin of $B$. sacra in acetic acid-induced writhing and formalin tests demonstrated the antinociceptive properties of $B$. sacra as a traditional medicinal plant [16].

7.3. Hepatoprotective Effects. Biological evaluations of cembrane-type diterpenes isolated from $B$. sacra showed that some of these compounds exhibited obvious hepatoprotective effects against paracetamol-induced HepG2 cell damage [26]. Administration of the water extract of oleo-gum-resin of $B$. sacra in rats demonstrated that this plant possesses hepatoprotective activity against carbon tetrachloride-induced acute and chronic hepatic damage [43]. 
<smiles>CCO[C@H]1C=C2[C@@H]3[C@@H](C)[C@@H](C)CC[C@]3(C)CC[C@]2(C)[C@@]2(C)CC[C@@H]3[C@](C)(CC[C@H](O)[C@@]3(C)C(=O)O)[C@H]12</smiles>

80

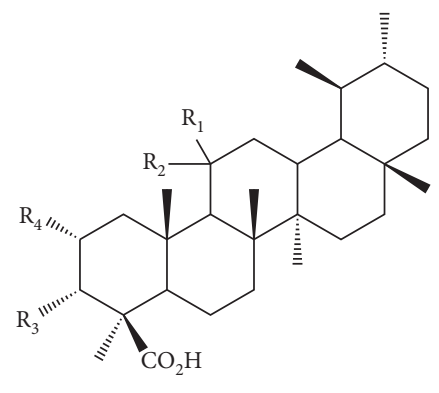

$$
\begin{array}{ll}
81 & \mathrm{R}_{1}=\mathrm{R}_{2}=\mathrm{R}_{4} \mathrm{H}, \mathrm{R}_{3} \mathrm{OH} \\
82 & \mathrm{R}_{1}+\mathrm{R}_{2}=\mathrm{O}, \mathrm{R}_{3} \mathrm{OAc}, \mathrm{R}_{4} \mathrm{H} \\
83 & \mathrm{R}_{1}+\mathrm{R}_{2}=\mathrm{O}, \mathrm{R}_{3} \mathrm{OH}, \mathrm{R}_{4} \mathrm{H} \\
84 & \mathrm{R}_{1}+\mathrm{R}_{2}=\mathrm{H}, \mathrm{R}_{3}=\mathrm{R}_{4} \mathrm{OH}
\end{array}
$$

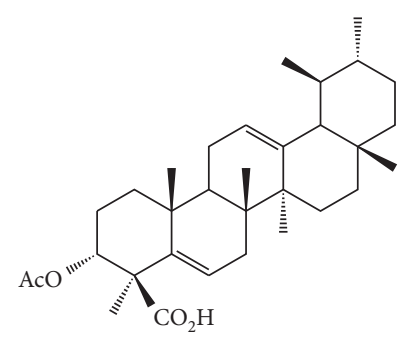

85

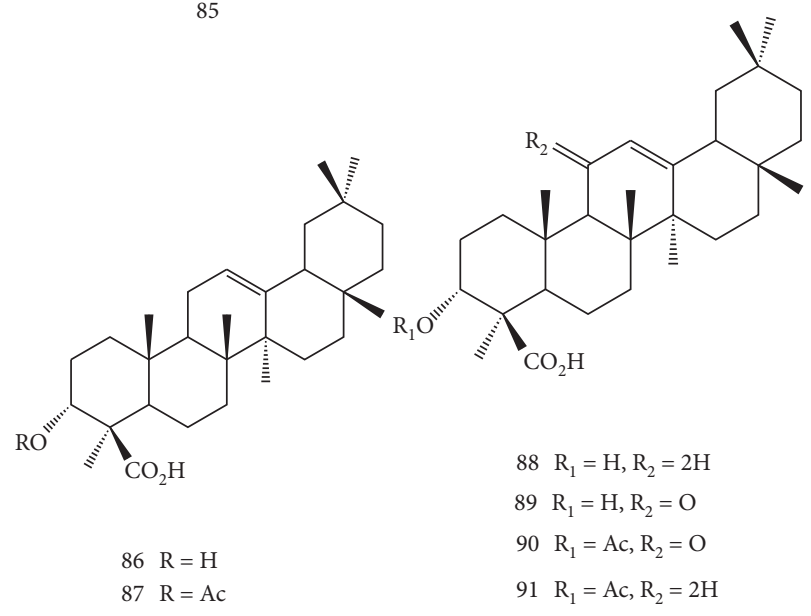<smiles>C[C@H]1CC[C@]2(C)CC[C@]3(C)C(=CC=C4[C@@]5(C)CC[C@H](O)[C@](C)(C(=O)O)C5CC[C@]43C)C2[C@@H]1C</smiles>

92

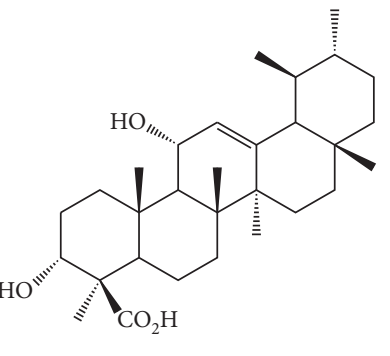<smiles>C[C@H]1CC[C@]2(C)CC[C@]3(C)C(=CCC4[C@@]5(C)CC[C@@H](O)[C@](C)(C(=O)O)C5CC[C@]43C)C2[C@@H]1C</smiles>

94

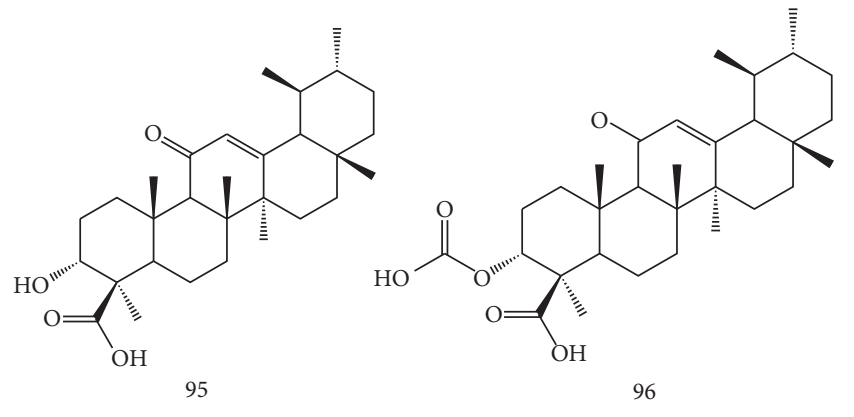

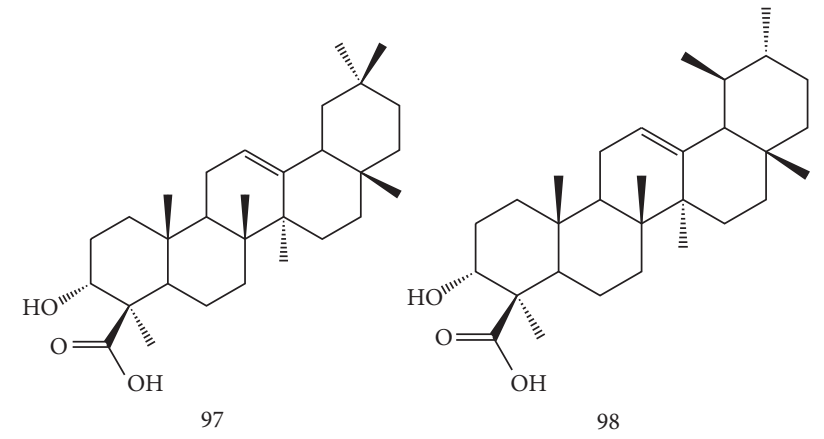

(b)

(a)

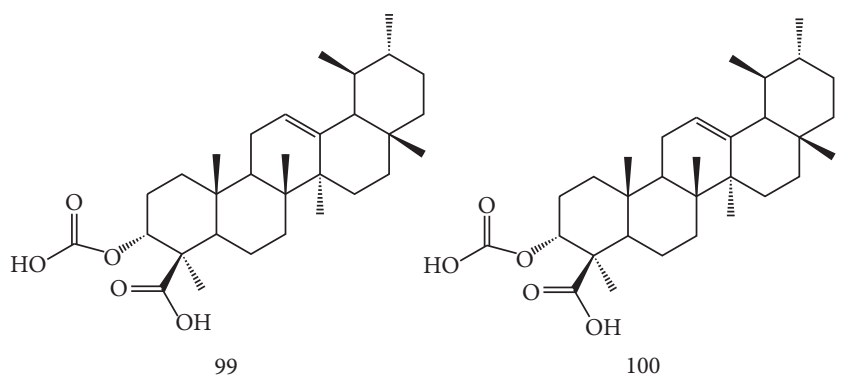

(c)

Figure 8: Structure of isolated boswellic acids and derivatives from B. sacra. 


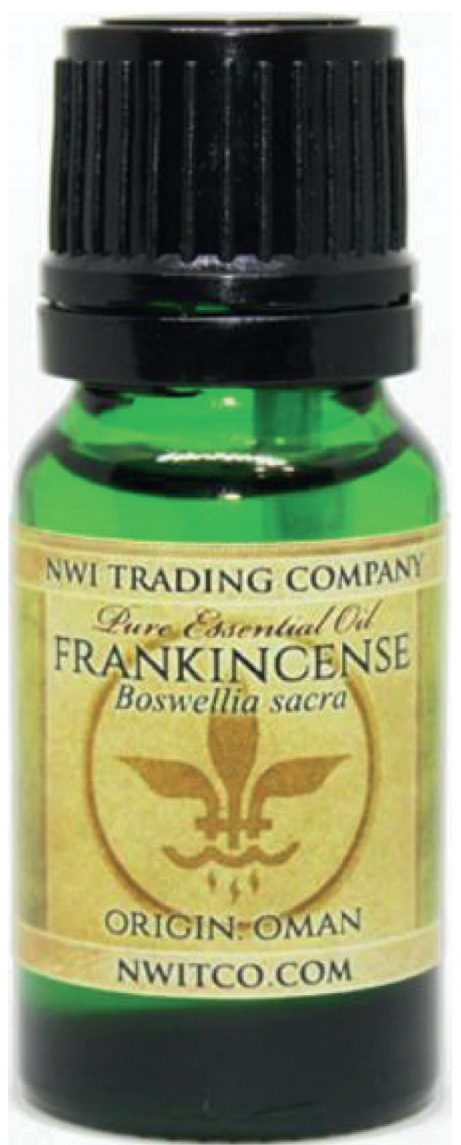

Figure 9: Frankincense B. sacra essential oil (https://www.amazon. com).

7.4. Antimicrobial Effects. Essential oils from B. sacra have been traditionally used to treat microbial and fungal infections. In vitro study of monoterpenoids of $B$. sacra essential oil showed antimicrobial activity against Staphylococcus aureus, Pseudomonas aeruginosa, and Propionibacterium acnes. Frankincense essential oils also exhibited a significant antifungal effect against Candida albicans and Malassezia furfur [2].

The inhibitory effect of different concentrations of $B$. sacra resin, leaf extract, and essential oil has been evaluated on the growth and production of aflatoxins by Aspergillus flavus and Aspergillus parasiticus. This study revealed that the resin powder and essential oil of B. sacra markedly reduce aflatoxin production. Therefore, the resin powder and essential oil of $B$. sacra can be recommended as safe natural food preservatives to increase the shelf life of food and feed products with reference to their antimicrobial and aflatoxin inhibitory activities [44]. In another study, it was found that B. sacra oleoresin extract has a promising antibacterial and antibiofilm activity against Porphyromonas gingivalis [45]. Moreover, the potential of $B$. sacra extract was evaluated against a number of human gastrointestinal bacterial pathogens and autoimmune disease-stimulating bacteria in combination with conventional antibiotics. In this regard, the obtained results confirmed that the combination of conventional antibiotics with B. sacra extracts exhibited extremely higher activity than that of the individual components alone [46]. Recently, a research study revealed that $\mathrm{B}$. sacra essential oil exhibited promising antifungal activity against some fungi species which lead to strawberry rot such as Botrytis cinerea, Aspergillus niger, and Rhizopus stolonifera [47].

7.5. Antioxidant Effects. It has been shown that the essential oil of B. sacra gum resin has a strong antioxidant effect in the DPPH radical scavenging method. However, its antioxidant activity is lower as compared to the antioxidant property of ascorbic acid [48]. The effect of $B$. sacra oleo gum resin extract has been studied against testicular toxicity in rats. The extract of this plant decreased the gene expression of HSP70 (heat shock protein-70), GSTPi (glutathione-s-transferase-Pi), and IGFBP3 (insulin-like growth factor binding protein-3) in the testes. The result of this study suggests that the antioxidant effect of $B$. sacra may protect the testes against several toxicants through the inhibition of free radicals [1]. Moreover, recent evidence indicated that incorporation of $B$. sacra essential oil into nanoparticles enhanced the efficacy of some pharmacological properties such as antioxidant activity [49].

7.6. Anti-Alzheimer Effect. The genus Boswellia has been suggested to cure or prevent neurodegenerative disorders through anti-inflammatory, antioxidative, antiamyloidogenic, and antiapoptotic effects [50]. Evaluating the effect of essential oil obtained from resins of $B$. sacra showed that frankincense essential oil can significantly inhibit the acetylcholinesterase enzyme (AChE). Inhibition of $\mathrm{AChE}$ leads to increased acetylcholine levels in the brain and improves memory in Alzheimer's disease patients. Therefore, B. sacra as a medicinal plant may protect against memory loss from Alzheimer's disease [51].

7.7. Anti-Inflammatory Effect. The anti-inflammatory effects of essential oil from $B$. sacra have been studied on an ovalbumin-induced allergic asthma mouse model. The results of this evaluation showed that inhalation of B. sacra essential oil has a potential therapeutic effect in allergic airway inflammation through increasing Th1 cytokine (IFN- $\gamma$ ) and decreasing Th2 cytokines (IL-4, IL-5, and IL-13) levels [52].

7.8. Antiseizure Effect. More recently, Wolfender and coworkers reported a comprehensive study on the antiseizure activity of resin of $B$. sacra. Results of this study demonstrated that among all isolated terpenoids, $\beta$-boswellic acid which belongs to triterpenoid derivatives was the most active and resulted in a $90 \%$ reduction of pentylenetetrazole (PTZ)induced seizures at $100 \mu \mathrm{g} / \mathrm{mL}$ [53]. The pharmacological activity of $B$. sacra gum resin and its phytochemicals is summarized in Table 1.

\section{Future Perspectives}

It is strongly believed that detailed information on the phytochemical and biological activities of $B$. sacra, as presented in this review, provides certain evidence for the use of 
TABLE 1: The pharmacological profiles of B. sacra gum resin and its phytochemicals.

\begin{tabular}{|c|c|c|c|c|c|c|}
\hline Activity & $\begin{array}{l}\text { Extract/ } \\
\text { compounds }\end{array}$ & $\begin{array}{c}\text { Dose and } \\
\text { treatment period }\end{array}$ & Model & Results & Mechanism & Reference \\
\hline \multirow{3}{*}{ Anticancer } & $\begin{array}{l}\text { Essential oil, } \\
\text { 11-keto-b- } \\
\text { boswellic acid }\end{array}$ & $100 \mu \mathrm{l}$, treat, $24 \mathrm{~h}$ & $\begin{array}{c}\text { T47D, MCF7, MDA-MB- } \\
\text { 231, MCF10-2A }\end{array}$ & $\begin{array}{l}\text { Reduced cell viability, elevated } \\
\text { cell death, suppressed cellular } \\
\text { network formation, disrupted } \\
\text { spheroid development of breast } \\
\text { cancer cells, caused the } \\
\text { breakdown of multicellular } \\
\text { tumor spheroids (T47D), no } \\
\text { cytotoxity on MCF10-2A, } \\
\text { inhibited caspases in the MDA- } \\
\text { MB-231, anti-invasive }\end{array}$ & $\begin{array}{c}\text { (+) cleaved caspase- } \\
3(-) \text { caspase- } 8 \text { p43/p41, } \\
\text { caspase-9 p37/p35, pro- } \\
\text { caspase-3, Akt, PARP, } \\
\text { ERK1/2(Thr202/ } \\
\text { Tyr204), cdk4, cyclin } \\
\text { D1 }\end{array}$ & $\begin{array}{c}{[32,35,} \\
39]\end{array}$ \\
\hline & Essential oil & $\begin{array}{l}3 \mathrm{~mL} \text { daily, oral, } \\
25 \text { months }\end{array}$ & $\begin{array}{l}\text { A 52-year-old male with } \\
\text { urothelial cell carcinoma }\end{array}$ & $\begin{array}{l}\text { Suppressed viability, reduced } \\
\text { cell growth, antiproliferative, } \\
\text { antiapoptotic, induced } \\
\text { cytotoxicity, reduced tumor } \\
\text { volume, anti-tumor }\end{array}$ & $\begin{array}{c}(+) \text { Caspase-3 } \\
\text { activation, apoptosis(-) } \\
\text { cyclin D1, cdk4, } \\
\text { caspase-8 p43/p41, } \\
\text { caspase-9p37/p35, } \\
\text { procaspase-3, PARP, } \\
\text { Akt ser (473), ERK1/ } \\
\text { 2(Thr202/Tyr204), } \\
\text { proliferating } \\
\text { (+) No(-) AST, ALT, } \\
\text { bilirubin, creatinine, } \\
\text { BUN }\end{array}$ & {$[42]$} \\
\hline & $\begin{array}{l}\text { Methanolic } \\
\text { extract, } \\
\text { Boswellic acids }\end{array}$ & $\begin{array}{l}6.25-100 \mu \mathrm{g} / \mathrm{ml}, \\
\text { incubated, } 24 \\
\text { and } 48 \mathrm{~h}\end{array}$ & $\begin{array}{c}\text { Human pancreatic } \\
\text { (PANC1), colon } \\
\text { (HCT116), lung } \\
\text { adenocarcinoma (MOR), } \\
\text { breast cancer MCF7 and } \\
\text { MDA-MB-231, the human } \\
\text { prostate cancer LNCaP, } \\
\text { and SerBob cell lines }\end{array}$ & $\begin{array}{l}\text { Inhibited tumor growth, } \\
\text { anticancer, improved kidney } \\
\text { and liver function, decreased } \\
\text { tumor volume } \\
\text { Anti-tumor cytotoxicity, } \\
\text { inhibited cell viability }\end{array}$ & $(+)-(-)-$ & {$[55]$} \\
\hline $\begin{array}{l}\text { Anti- } \\
\text { inflammatory }\end{array}$ & Essential oil & $\begin{array}{l}0.3 \% \text {, inhalation, } \\
8 \text { weeks }\end{array}$ & $\begin{array}{l}\text { Ovalbumin-induced } \\
\text { BALB/c mice allergic } \\
\text { asthma }\end{array}$ & $\begin{array}{c}\text { Reduced eosinophils, } \\
\text { decreased goblet cell } \\
\text { hyperplasia, inhibited } \\
\text { hyperresponsiveness, anti- } \\
\text { inflammatory, immunity }\end{array}$ & $\begin{array}{l}\text { (+) Th1, IFN- } \gamma,(-) \\
\text { Th2, IL- } 4, \text { IL-5, IL-13, } \\
\mathrm{CD}^{+}, \mathrm{CD}^{+} / \mathrm{CCR}^{+}, \\
\text {B } 220^{+} / \mathrm{CD} 23^{+}\end{array}$ & {$[51]$} \\
\hline Analgesic & $\begin{array}{l}\text { Methanolic } \\
\text { extract, essential } \\
\text { oils, } \\
\text { subfractions }\end{array}$ & $\begin{array}{l}300 \mathrm{mg} / \mathrm{kg} \text {, } \\
\text { orally }\end{array}$ & $\begin{array}{l}\text { Acetic acid-induced } \\
\text { writhes and formalin- } \\
\text { induced pain in mice }\end{array}$ & $\begin{array}{l}\text { Analgesic, inhibited writhes, } \\
\text { inhibited licking, and biting } \\
\text { response }\end{array}$ & $(+) \mathrm{No}(-) \mathrm{No}$ & {$[32]$} \\
\hline \multirow[t]{5}{*}{ Antimicrobial } & Essential oil & $0.1 \mathrm{ml}$, treat, $24 \mathrm{~h}$ & $\begin{array}{c}\text { Staphylococcus aureus } \\
\text { (ATCC 25923; ATCC } \\
\text { 6538), Pseudomonas } \\
\text { aeruginosa (ATCC 15442; } \\
\text { ATCC 9027), Candida } \\
\text { albicans (ATCC 10231), } \\
\text { Malassezia furfur (ATCC } \\
\text { 14521) }\end{array}$ & Antifungal, antimicrobial & $(+) \mathrm{No}(-)$ No & {$[2]$} \\
\hline & $\begin{array}{l}\text { Resin essential } \\
\text { oil }\end{array}$ & $\begin{array}{l}2.5,5,7.5,10 \mathrm{~g} / \\
100 \mathrm{ml}, 2,3 \\
4 \mathrm{ml} / 100 \mathrm{ml} \\
\text { incubated, } 15 \\
\text { days }\end{array}$ & $\begin{array}{c}\text { Aspergillus flavus (SQU21), } \\
\text { Aspergillus parasiticus } \\
\text { (CBS921.7) }\end{array}$ & $\begin{array}{l}\text { Inhibited microbial and } \\
\text { aflatoxins, enhanced fungal } \\
\text { growth, inhibited aflatoxin } \\
\text { biosynthesis and secretion } \\
\text { pathway }\end{array}$ & $\begin{array}{l}\text { (+) Mycelial dry } \\
\text { weights(-) Inhibited } \\
\text { fungal growth and } \\
\text { aflatoxins production }\end{array}$ & {$[4]$} \\
\hline & $\begin{array}{l}\text { Essential oil, }(+) \\
\text { pinene }\end{array}$ & $\begin{array}{c}0.5 \mathrm{mg} / \mathrm{ml}, \\
\text { incubated, } \\
15 \mathrm{~min}\end{array}$ & AChE, Jack bean urease & $\begin{array}{l}\text { Anti-Alzheimer's disease, } \\
\text { protected stomach ulcers }\end{array}$ & $\begin{array}{l}(+) \mathrm{No}(-) \mathrm{AChE} \\
\text { urease enzyme }\end{array}$ & {$[50]$} \\
\hline & $\begin{array}{l}\text { Diterpenoids of } \\
\text { ethanolic } \\
\text { extract }\end{array}$ & $\begin{array}{c}10 \mu \mathrm{M} \\
\text { incubated, } 1 \mathrm{~h}\end{array}$ & $\begin{array}{l}\text { Glutamate-induced } \\
\text { toxicity rat cortical }\end{array}$ & Neuroprotection & $(+) \mathrm{No}(-)$ No & {$[26]$} \\
\hline & $\begin{array}{l}\text { Boswellic acids, } \\
\text { ethyl acetate } \\
\text { fraction }\end{array}$ & $\begin{array}{l}0.75 \mathrm{mM}, 0.23 \\
0.46,0.93 \mathrm{mg} / \mathrm{ml}, \\
\text { incubated, } \\
20 \mathrm{~min}\end{array}$ & $\begin{array}{l}\text { neurons, human } \\
\text { neuroblastoma SK-N-SH } \\
\text { cellsAChE model }\end{array}$ & Anti-Alzheimer's disease & $(+) \mathrm{No}(-)$ AChE & {$[18]$} \\
\hline
\end{tabular}


TABle 1: Continued.

\begin{tabular}{|c|c|c|c|c|c|c|}
\hline Activity & $\begin{array}{c}\text { Extract/ } \\
\text { compounds }\end{array}$ & $\begin{array}{l}\text { Dose and } \\
\text { treatment period }\end{array}$ & Model & Results & Mechanism & Reference \\
\hline \multirow[b]{2}{*}{ Hepatoprotective } & $\begin{array}{l}\text { Diterpenoids of } \\
\text { ethanolic } \\
\text { extract }\end{array}$ & $\begin{array}{c}10 \mu \mathrm{M} \\
\text { incubated, } 1 \mathrm{~h}\end{array}$ & $\begin{array}{l}\text { Paracetamol-induced } \\
\text { HepG2 cells }\end{array}$ & $\begin{array}{c}\text { Hepatoprotective, inhibited } \\
\text { damage }\end{array}$ & $(+) \mathrm{No}(-) \mathrm{No}$ & {$[25,26]$} \\
\hline & $\begin{array}{l}\text { Methanolic } \\
\text { extract }\end{array}$ & $\begin{array}{l}250,500 \text { and } \\
1000 \mathrm{mg} / \mathrm{kg}, \\
\text { oraly, } 28 \text {-day }\end{array}$ & $\begin{array}{l}\text { Safety and toxicological } \\
\text { studies on rat }\end{array}$ & $\begin{array}{c}\text { Reduced mean cellular } \\
\text { hemoglobin }(\mathrm{MCH}) \text {, induced } \\
\text { hypochromic normocytic } \\
\text { anemia, may not be safe to use }\end{array}$ & $(+)-(-)-$ & [55] \\
\hline Wound healing & $\begin{array}{l}\text { Methanolic } \\
\text { extracts }\end{array}$ & $\begin{array}{c}10-20 \mu \mathrm{g} / \mathrm{ml}, \\
\text { incubated, } 24 \mathrm{~h}\end{array}$ & $\begin{array}{c}\mathrm{H}_{2} \mathrm{O}_{2} \text { - induced injury on } \\
\text { adult human dermal } \\
\text { fibroblasts }\end{array}$ & $\begin{array}{l}\text { Improved proliferation, } \\
\text { migration, and wound healing } \\
\text { process }\end{array}$ & (+) pERK/ERK(-) ROS & [56] \\
\hline
\end{tabular}

Note. (+): increased or activated; (-): decreased or inhibited.

this plant in different medicines and future pharmaceutical studies. It seems that the oleo gum resin of $B$. sacra is an important resource in the appearance of new drugs and herbal medicine formulations. However, more determining the pharmacological activity of B. sacra, especially in future clinical studies, is suggested. It is better that should have been a correlation between traditional uses of $B$. sacra and new studies. Further studies are needed to isolate the active compounds for the observed pharmacological activities. Also, the herbal medicine formulation should be prepared and standardized on the basis of the active compounds. Further studies should be focused on the mechanisms behind the anti-inflammatory and memory improvement activities and those biological activities that have been reported traditionally.

\section{Conclusion}

This present work was designed to show that B. sacra is a valuable medicinal plant and an interesting subject to researchers. Many studies have indicated that B. sacra is a rich source of terpenoid compounds, especially triterpenoids, responsible for a wide range of biological activities. Although different studies have investigated these, there is no data on the clinical effectiveness of $B$. sacra. The findings of this review study on $B$. sacra suggested that clinical trial studies should be undertaken to explore the anti-inflammatory activity and memory improvement effects. B. sacra has a long and brilliant history in traditional medicine, and that is why clinical trial studies are strongly recommended for its drug development.

\section{Conflicts of Interest}

The authors declare that they have no conflicts of interest.

\section{References}

[1] A. A. I. Al-Yahya, M. Asad, A. Sadaby, and M. S. Alhussaini, "Repeat oral dose safety study of standardized methanolic extract of Boswellia sacra oleo gum resin in rats," Saudi Journal of Biological Sciences, vol. 27, no. 1, pp. 117-123, 2020.

[2] V. Di Stefano, D. Schillaci, M. G. Cusimano, M. Rishan, and L. Rashan, "In vitro antimicrobial activity of frankincense oils from Boswellia sacra grown in different locations of the
Dhofar region (Oman)," Antibiotics, vol. 9, no. 4, Article ID 195, 2020.

[3] S. Al-Saidi, K. B. Rameshkumar, A. Hisham, N. Sivakumar, and S. Al-Kindy, "Composition and antibacterial activity of the essential oils of four commercial grades of Omani luban, the oleo-gum resin of Boswellia sacraFlueck," Chemistry and Biodiversity, vol. 9, no. 3, pp. 615-624, 2012.

[4] P. S. El-Nagerabi, A. Elshafie, and S. Alkhanjari, "Endophytic fungi associated with endogenous Boswellia sacra," Biodiversitas, vol. 15, pp. 24-30, 2014.

[5] A. L. Khan, A. Al-Harrasi, R. Shahzad et al., "Regulation of endogenous phytohormones and essential metabolites in frankincense-producing Boswellia sacra under wounding stress," Acta Physiologiae Plantarum, vol. 40, no. 6, Article ID $113,2018$.

[6] A. Al-Harrasi, N. U. Rehman, A. L. Khan et al., "Chemical, molecular and structural studies of Boswellia species: $\beta$-boswellic aldehyde and 3-epi-11 $\beta$-dihydroxy BA as precursors in biosynthesis of boswellic acids," PLoS One, vol. 13, no. 6, 2018.

[7] R. Atta-ur-Rahman, H. Naz, Fadimatou et al., "Bioactive constituents from Boswellia papyrifera," Journal of Natural Products, vol. 68, no. 2, pp. 189-193, 2005.

[8] D. C. Daly, M. M. Harely, M. C. Martinez-Habibe, and A. Weeks, "Burseraceae," in The Families and Genera of Vascular Plants, K. Kubitzki, Ed., Springer, Berlin, Germany, 2011.

[9] M. Z. Siddiqui, "Boswellia serrata, a potential antiinflammatory agent: an overview," Indian Journal of Pharmaceutical Sciences, vol. 73, no. 3, pp. 255-261, 2011.

[10] M. Thulin and A. M. Warfa, "The frankincense trees (Boswellia spp., Burseraceae) of northern Somalia and southern Arabia,” Kew Bulletin, vol. 42, no. 3, pp. 487-500, 1987.

[11] C. L. Woolley, M. M. Suhail, B. L. Smith et al., "Chemical differentiation of Boswellia sacra and Boswellia carterii essential oils by gas chromatography and chiral gas chromatography-mass spectrometry," Journal of Chromatography A, vol. 1261, pp. 158-163, 2012.

[12] F. A. Flückiger, Lehrbuch der Pharmakognosie des Pflanzenreiches, Naturgeschichte der wichtigeren Arzneistoffe vegetabilischen Ursprungen, Berlin, Germany, 1867.

[13] H. J. Carter, "A description of frankincense tree of Arabia, with remarks on the misplacements of the "Libanophorous Region" in Ptolemy's Geography," Journal of the Asiatic Society of Mumbai, vol. 2, pp. 380-390, 1847.

[14] F. A. "Flückiger, "Ueber den weihrauchbaum," Scweiz. Wochenschr. Pharm.vol. 2, no. 19, pp. 129-141, 1864.

[15] M. M. Iwo, Handbook of African Medicinal Plants, CRC Press, Boca Raton, FL, USA, 2014. 
[16] A. Al-Harrasi, L. Ali, J. Hussain et al., "Analgesic effects of crude extracts and fractions of Omani frankincense obtained from traditional medicinal plant Boswellia sacra on animal models," Asian Pacific Journal of Tropical Medicine, vol. 7, pp. S485-S490, 2014.

[17] A. Al-Harrasi, L. Ali, N. U. Rehman et al., "Nine triterpenes from Boswellia sacra Flückiger and their chemotaxonomic importance," Biochemical Systematics and Ecology, vol. 51, pp. 113-116, 2013.

[18] M. Ota and P. J. Houghton, "Boswellic acids with acetylcholinesterase inhibitory properties from frankincense," Natural Product Communications, vol. 3, no. 1, 2008.

[19] B. Büchele, W. Zugmaier, and T. Simmet, "Analysis of pentacyclic triterpenic acids from frankincense gum resins and related phytopharmaceuticals by high-performance liquid chromatography. Identification of lupeolic acid, a novel pentacyclic triterpene," Journal of chromatography. B, Analytical technologies in the biomedical and life sciences, vol. 791, no. 1-2, pp. 21-30, 2003.

[20] S. Hamm, J. Bleton, J. Connan, and A. Tchapla, "A chemical investigation by headspace SPME and GC-MS of volatile and semi-volatile terpenes in various olibanum samples," Phytochemistry, vol. 66, no. 12, pp. 1499-1514, 2005.

[21] B. Najar, J. E. Shortrede, L. Pistelli, and J. Buhagiar, "Chemical composition and in vitro cytotoxic screening of sixteen commercial essential oils on five cancer cell lines," Chemistry and Biodiversity, vol. 17, no. 1, Article ID e1900478, 2020.

[22] A. Al-Riyami, N. Al-Manthary, S. N. Al-Busafi, and S. H. AlSaidi, "Comparison of chemical composition and antioxidant activity of essential oil of gum-resin obtained from Juniperus excelsa and Boswellia sacra," Asian Journal of Chemistry, vol. 29, no. 11, pp. 2570-2574, 2017.

[23] A. Al-Harrasi and S. Al-Saidi, "Phytochemical analysis of the essential oil from botanically certified oleogum resin of Boswellia sacra (Omani Luban)," Molecules, vol. 13, no. 9, pp. 2181-2189, 2008.

[24] J. Niebler, K. Zhuravlova, M. Minceva, and A. Buettner, "Fragrant sesquiterpene ketones as trace constituents in frankincense volatile oil of Boswellia sacra," Journal of Natural Products, vol. 79, no. 4, pp. 1160-1164, 2016.

[25] J. Wang, B. Zhen, J. Hu et al., "Boscartins L-O: cembrane-type diterpenoids from the gum resin of Boswellia sacra Flueck," Phytochemistry, vol. 163, pp. 126-131, 2019.

[26] J. J. Wang, H. R. Sun, X. Y. Suo et al., "Ten undescribed cembrane-type diterpenoids from the gum resin of Boswellia sacra and their biological activities," Phytochemistry, vol. 177, Article ID 112425, 2020.

[27] B. Zhang, D. Liu, W. Ji et al., "Bioactive cembranoids from gum resin of Boswellia sacra," Frontiers of Chemistry, vol. 9, 2021.

[28] J. J. Wang, X. Y. Suo, H. R. Sun et al., "Prenylaromadendranetype diterpenoids from the gum resin of Boswellia sacra flueck and their cytotoxic effects," Natural Product Research, vol. 1-7, 2021.

[29] C. Mathe, G. Culioli, P. Archier, and C. Vieillescazes, "HighPerformance liquid chromatographic analysis of triterpenoids in commercial frankincense," Chromatographia, vol. 60, no. 9, pp. 493-499, 2004.

[30] L. Ali, J. Hussain, A. Al-Rawahi, and A. Al-Harrasi, "Two new and four known triterpenoids from Boswellia sacra fluckiger," Records of Natural Products, vol. 8, Article ID 407, 2014.

[31] A. Al-Harrasi, H. Hussain, J. Hussain et al., "Two pyrolysate products from Omani frankincense smoke: first evidence of thermal aromatization of boswellic acids," Journal of Analytical and Applied Pyrolysis, vol. 110, pp. 430-434, 2014.

[32] A. Al-Harrasi, L. Ali, N. Rehman et al., " $11 \alpha$-Ethoxy- $\beta$-boswellic acid and nizwanone, a new boswellic acid derivative and a new triterpene respectively, from Boswellia sacra," Chemistry and Biodiversity, vol. 10, Article ID 1501, 2013.

[33] G. Mannino, A. Occhipinti, and M. E. Maffei, "Quantitative determination of 3-O-Acetyl-11-Keto- $\beta$ Boswellic acid (AKBA) and other boswellic acids in Boswellia sacra flueck (syn. B. Carteri birdw) and Boswellia serrata Roxb," Molecules, vol. 21, no. 10, 2016.

[34] N. Rehman, A. Khan, A. Al-Harrasi et al., "New $\alpha$-Glucosidase inhibitors from the resins of Boswellia species with structureglucosidase activity and molecular docking studies," Bioorganic Chemistry, vol. 79, pp. 27-33, 2018.

[35] A. Bini Araba, N. Ur Rehman, A. Al-Araimi et al., "New derivatives of 11 -keto- $\beta$-boswellic acid (KBA) induce apoptosis in breast and prostate cancers cells," Natural Product Research, vol. 35, pp. 1-10, 2019.

[36] M. V. Karlina, O. N. Pozharitskaya, V. M. Kosman, and S. A. Ivanova, "Bioavailability of boswellic acids: in vitro/in vivo correlation," Pharmaceutical Chemistry Journal, vol. 41, no. 11, pp. 569-572, 2007.

[37] H. Hussain, A. Al-Harrasi, R. Csuk et al., "Therapeutic potential of boswellic acids: a patent review (1990-2015)," Expert Opinion on Therapeutic Patents, vol. 27, no. 1, pp. 81-90, 2017.

[38] N. K. Roy, D. Parama, K. Banik et al., "An update on pharmacological potential of boswellic acids against chronic diseases," International Journal of Molecular Sciences, vol. 20, no. 17, Article ID 4101, 2017.

[39] M. M. Suhail, W. Wu, A. Cao et al., "Boswellia sacra essential oil induces tumor cell-specific apoptosis and suppresses tumor aggressiveness in cultured human breast cancer cells," BMC Complementary and Alternative Medicine, vol. 11, Article ID 129, 2011.

[40] X. Ni, M. M. Suhail, Q. Yang et al., "Frankincense essential oil prepared from hydrodistillation of Boswellia sacra gum resins induces human pancreatic cancer cell death in cultures and in a xenograft murine model," BMC Complementary and Alternative Medicine, vol. 12, Article ID 253, 2012.

[41] E. Becer, H. Kabadayi, K. H. C. Baser, and H. S. Vatansever, "Boswellia sacra essential oil manages colon cancer stem cells proliferation and apoptosis: a new perspective for cure," Journal of Essential Oil Research, vol. 53-62, 2020.

[42] D. Xia, W. Lou, K.-M. Fung, C. L. Wolley, M. M. Suhail, and H.-K. Lin, "Cancer chemopreventive effects of Boswellia sacra gum resin hydrodistillates on invasive urothelial cell carcinoma: report of a case," Integrative Cancer Therapies, vol. 16, no. 4, pp. 605-611, 2017.

[43] M. Asad and M. Alhumoud, "Hepatoprotective effect and GCMS analysis of traditionally used Boswellia sacra oleo gum resin (Frankincense) extract in," African Journal of Traditional, Complementary and Alternative Medicines, vol. 12, no. 2, pp. 1-6, 2015.

[44] S. A. F. El-Nagerabi, A. E. Elshafie, S. S. AlKhanjari, S. N. AlBahry, and M. R. Elamin, "Biological activities of Boswellia sacra extracts on the growth and aflatoxins secretion of two aflatoxigenic species of Aspergillus species," Food Control, vol. 34, no. 2, pp. 763-769, 2013.

[45] N. G. M. Attallah, W. A. Negm, E. Elekhnawy et al., "Antibacterial activity of Boswellia sacra flueck. Oleoresin extract against Porphyromonas gingivalis periodontal pathogen," Antibiotics, vol. 10, Article ID 859, 2021. 
[46] L. Rashan, A. White, M. Haulet, N. Favelint, P. Das, and I. Edwin Cock, "Chemical composition, antibacterial activity, and antibiotic potentiation of Boswellia sacra flueck. Oleoresin Extracts from the dhofar Region of Oman," Evidence-based Complementary and Alternative Medicine, vol. 2021, Article ID 9918935, 23 pages, 2021.

[47] M. Rahmati-Joneidabad and B. Alizadeh Behbahani, "Boswellia sacra essential oil: antioxidant activity and antifungal effect on some spoilage fungi causing strawberry rot," Iranian Journal of Food Science and Technology, vol. 18, no. 114, 2021.

[48] A. Al-Harrasi, A. Al-Rawahi, J. Hussain et al., "Antiglycation and antioxidant activities and the HPTLC analysis of Boswellia sacra resin: the sacred frankincense," Tropical Journal of Pharmaceutical Research, vol. 12, Article ID 597, 2013.

[49] M. Soltani, A. Etminan, A. Rahmati, M. Behjati Moghadam, G. Ghaderi Segonbad, and M. Homayouni Tabrizi, "Incorporation of Boswellia sacra essential oil into chitosan/TPP nanoparticles towards improved therapeutic efficiency," Materials Technology, 2021.

[50] A. Rajabian, H. Sadeghnia, S. Fanoudi, and A. Hosseini, "Genus Boswellia as a new candidate for neurodegenerative disorders," Journal of Basic Medical Sciences, vol. 23, no. 3, pp. 277-286, 2020.

[51] G. Abbas, M. A. Albroumi, N. U. Rehman, H. Hussain, and A. S. Al-Harrasi, "Evaluation of essential oils from Boswellia sacra and Teucrium mascatense against acetyl cholinesterase enzyme and urease enzyme," International Journal of Phytomedicine, vol. 8, no. 4, 2016.

[52] H. Y. Lee, M. Y. Yun, and S. M. Kang, “Anti-inflammatory effect of Boswellia sacra (Franckincense) essential oil in a mouse model of allergic asthma," Korean Journal of Microbiology and Biotechnology, vol. 36, pp. 343-352, 2008.

[53] T. Brillatz, M. Jacmin, E. F. Queiroz et al., "Identification of potential antiseizure agents in Boswellia sacra using in vivo zebrafish and mouse epilepsy models," ACS Chemical Neuroscience, vol. 12, no. 10, pp. 1791-1801, 2021.

[54] P. Parsonidis, I. Vlachou, A. Mamagkaki, I. Bouris, V. Daikopoulou, and I. Papasotiriou, "Cytotoxic effect of Boswellia sacra on human cancer cell lines," Journal of Cancer Science \& Therapy, vol. 13, no. 7, 2021.

[55] A. A. I. Alyahya, M. Asad, S. M. Basheeruddin Asdaq et al., "Haematotoxic effects of methanolic extract of Boswellia sacra oleo gum resin (frankinccense) in rats," Science Progress, vol. 104, no. 2, pp. 1-8, 2021.

[56] A. Kavousi, E. Nikkhah, Z. Tayarani-Najaran, and B. Javadi, "Wound healing effects and related mechanisms of action of methanol extracts of Boswellia sacra and Commiphora myrrha oleo-gum-resins on adult human dermal fibroblasts (HDFa)," SSRN Electronic Journal, vol. 1-17, 2021. 